ACTA UNIVERSITATIS WRATISLAVIENSIS

No 3978

PRZEGLĄD PRAWA I ADMINISTRACJI CXX/2

WROCŁAW 2020

https://doi.org/10.19195/0137-1134.120.74

\author{
ŁUKASZ GOŹDZIASZEK \\ ORCID: 0000-0003-3843-5037 \\ Uniwersytet Wrocławski \\ Centrum Badań Problemów Prawnych i Ekonomicznych Komunikacji Elektronicznej
}

\title{
ELEKTRONICZNE POSTĘPOWANIE UPOMINAWCZE W ŚWIETLE CELÓW INFORMATYZACJI PODMIOTÓW PUBLICZNYCH
}

\begin{abstract}
Abstrakt: Elektroniczne postępowanie upominawcze było pierwszym udanym wdrożeniem informatycznym w procesie cywilnym. Przez dziesięć lat rola tego postępowania w systemie postępowania cywilnego była znacząca. Nadal ma potencjał do dalszego rozwoju. Regulacje prawne ulegały jednak wielokrotnym zmianom, a nowe przepisy prawne nie zawsze były trafne i spójne.

Słowa kluczowe: e-sąd, informatyzacja, postępowanie cywilne, elektroniczne postępowanie upominawcze, prawo
\end{abstract}

\section{ROLA ELEKTRONICZNEGO POSTĘPOWANIA UPOMINAWCZEGO}

Dziesięcioletni okres funkcjonowania elektronicznego postępowania upominawczego pozwala dokonać oceny trafności regulacji związanych z taką drogą dochodzenia roszczeń. Na wstępie należy podkreślić, że nie powinno budzić wątpliwości samo ustanowienie na gruncie polskiego procesu tego postępowania. W krótkim czasie osiągnęło ono stabilną i znaczną rolę w postępowaniu cywilnym (za punkt odniesienia do takiej oceny można nawet przyjmować wszystkie postępowania sądowe, czyli również karne i w sprawach o wykroczenia). Świadczy o tym nie tylko liczba spraw w nim rozpoznanych ${ }^{1}$, lecz także okoliczność, że przez ten okres nie powstało na szerszą skalę inne równie innowacyjne rozwiązanie w postępowaniu

1 Zob. analizy dotyczące liczby spraw w elektronicznym postępowaniu upominawczym: Ł. Goździaszek, Funkcjonowanie elektronicznego postępowania upominawczego, „Biuletyn Polskiego Towarzystwa Ekonomicznego" 2017, nr 2, s. 111-118; idem, Sprawność postępowania zwyktego, postepowania gospodarczego i elektronicznego postepowania upominawczego, [w:] Ochrona praw wierzycieli w Polsce - wymiar ekonomiczny, koszty transakcyjne, prawne formy zabezpieczeń, informatyzacja sądownictwa, red. J. Gołaczyński, E. Mączyńska, Warszawa 2017, s. 207-236; idem, Sytuacja spółek jako wierzycieli dochodzacych roszczeń w elektronicznym postępowaniu upominaw- 
sądowym. Co więcej, choć jeszcze nie tak dawno (w momencie obowiązywania art. 20 nowelizacji z lipca 2015 roku w pierwotnym kształcie ${ }^{2}$ ) wydawało się, że elektroniczne postępowanie upominawcze może zostać zmarginalizowane wskutek projektowanego uniwersalnego zinformatyzowania postępowania cywilnego ${ }^{3}$, takie zjawisko nie nastąpiło. Ustawodawca nowelizacją z 2019 roku wycofał się z całościowej i bezwarunkowej informatyzacji postępowania cywilnego. Ponadto wciąż żywe są dyskusje nad rozwojem elektronicznego postępowania upominawczego przez unowocześnienie zastosowanych w nim rozwiązań, głównie poprzez zwiększenie zakresu wykorzystania nowych narzędzi informatycznych ${ }^{4}$.

Choć nowelizacja z 2019 roku istotnie zmienia postępowanie cywilne, to zmiany w zakresie elektronicznego postępowania upominawczego trudno jednoznacznie scharakteryzować. Na szczegółowym poziomie mają one głównie charakter redakcyjny. Stosowanie nowych, ogólnych rozwiązań dotyczących doręczań pism w postępowaniu cywilnym zostało nawet faktycznie wyłączone w wypadku elektronicznego postępowania upominawczego (tak art. $505^{34} \S 1$ k.p.c. ${ }^{5}$ ). Niemniej jedna ze zmian, choć na poziomie skutków konkretnych czynności, może nie być znacząca, to jednak może być ujmowana jako symboliczne odmienne umiejscowienie elektronicznego postępowania upominawczego w strukturze systemu postępowania cywilnego. Przedmiotowe postępowanie pod rządami nowelizacji z 2019 roku nie stanowi już wstępnego elementu procesu, lecz jest odrębnym mechanizmem dochodzenia roszczeń. Nieuprawomocnienie się nakazu zapłaty wydanego w elektronicznym postępowaniu upominawczym (jak też niewydanie nakazu zapłaty lub jego uchylenie) od czasu nowelizacji z 2019 roku, w myśl art. $505^{33}$ k.p.c.,

czym, postepowaniu nakazowym i zwyktym postępowaniu cywilnym, „Biuletyn Polskiego Towarzystwa Ekonomicznego" 2016, nr 4, s. 66-70.

2 Ustawa z dnia 10 lipca 2015 roku o zmianie ustawy - Kodeks cywilny, ustawy - Kodeks postępowania cywilnego oraz niektórych innych ustaw (Dz.U. z 2015 r. poz. 1311 ze zm.), która weszła w życie 8 września 2016 roku; dalej: nowelizacja z lipca 2015 roku. Przywołany art. 20 tej nowelizacji został uchylony ustawą z dnia 4 lipca 2019 roku o zmianie ustawy - Kodeks postępowania cywilnego oraz niektórych innych ustaw (Dz.U. z 2019 r. poz. 1469), która weszła w życie 21 sierpnia 2019 roku; dalej: nowelizacja z 2019 roku.

3 Ł. Goździaszek, Elektroniczne postępowanie upominawcze po nowelizacji, [w:] Kodeks postępowania cywilnego z perspektywy pięćdziesięciolecia jego obowiązywania. Doświadczenia i perspektywy, red. E. Marszałkowska-Krześ, I. Gil, Ł. Błaszczak, Sopot 2016, s. 409-418.

4 K. Jasik-Kuchta, Proponowane zmiany w polskim elektronicznym postępowaniu upominawczym w świetle rozwiazań Online Civil Money Claims, „Monitor Prawa Handlowego” 2018, nr 4, s. 30 n.; J. Gołaczyński, e-Sąd przyszłości, „Monitor Prawniczy” 2019, nr 2, s. 97 n.; B. Kaczmarek-Templin, Zmiany w elektronicznym postepowaniu upominawczym i zmiany w elektronicznych doręczeniach w świetle nowelizacji Kodeksu postepowania cywilnego z 27.11.2017 r., „Prawo Mediów Elektronicznych" 2018, nr 2, s. 4 n.; Ł. Goździaszek, Perspektywy wykorzystania sztucznej inteligencji w postepowaniu sądowym, „Przegląd Sądowy” 2015, nr 10, s. 46 n.; idem, Perspektywy petnego zautomatyzowania elektronicznego postępowania upominawczego, [w:] E-obywatel. E-sprawiedliwość. E-usługi, red. K. Flaga-Gieruszyńska, J. Gołaczyński, D. Szostek, Warszawa 2017, s. 223 n.

5 Ustawa z dnia 17 listopada 1964 roku — Kodeks postępowania cywilnego (tekst jedn. Dz.U. z 2019 r. poz. 1460 ze zm.); dalej: k.p.c. 
art. $505^{34} \S 2$ k.p.c. lub art. $505^{36} \S$ k.p.c., skutkuje umorzeniem postępowania, a nie — jak dawniej — przekazaniem sprawy do sądu według właściwości ogólnej.

Nie następuje zatem symboliczna kontynuacja postępowania, lecz jednoznaczne zakończenie elektronicznego postępowania upominawczego. Jak jednak wskazano, na poziomie konkretnych instytucji odrębność ta zostaje mocno ograniczona - przede wszystkim art. $505^{37} \S 2$ zd. 1 k.p.c. stanowi, że jeżeli w terminie trzech miesięcy od dnia wydania postanowienia o umorzeniu elektronicznego postępowania upominawczego powód wniesie pozew przeciwko pozwanemu o to samo roszczenie w postępowaniu innym niż elektroniczne postępowanie upominawcze, skutki prawne, które ustawa wiąże $\mathrm{z}$ wytoczeniem powództwa, następują $\mathrm{z}$ dniem wniesienia pozwu w elektronicznym postępowaniu upominawczym. Wiąże to zatem dotychczasowe elektroniczne postępowanie upominawcze (które zostało umorzone) z nowym postępowaniem.

Cele ustawodawcy w zakresie przywołanej zmiany co do zakończenia elektronicznego postępowania upominawczego nie są w pełni jasne. $Z$ jednej strony zmiany w tym zakresie można uzasadnić chęcią rozwiązania dotychczasowych i zapobieżenia nowym problemom związanym z przekazywaniem spraw do sądu według właściwości ogólnej z sądu rozpoznającego sprawy w elektronicznym postępowaniu upominawczym. Problemy z tym związane dominowały wśród rozważań doktryny ${ }^{6}$ i judykatury ${ }^{7}$. $\mathrm{Z}$ drugiej zaś strony wiodąca mogła być chęć

6 J.R. Antoniuk, Postępowanie sadu właściwego po przekazaniu mu sprawy wniesionej w elektronicznym postepowaniu upominawczym (uwagi na tle art. 505[37] KPC), „Monitor Prawniczy” 2012, nr 20, s. 1069 n.; idem, Pozew i sprzeciw od nakazu zapłaty wniesione w elektronicznym postępowaniu upominawczym po przekazaniu sprawy do sądu właściwego (uwagi na tle znowelizowanego art. 505[37] k.p.c.), „Polski Proces Cywilny” 2015, nr 4, s. 512 n.; Ł. Goździaszek, Konsekwencje dla strony przekazania sprawy z e-sadu, [w:] Elektroniczne postępowanie upominawcze - doświadczenia i perspektywy, red. K. Flaga-Gieruszyńska, A. Jakubecki, J. Misztal-Konecka, Lublin 2017, s. 129 n.; A. Kościółek, Sprzeciw od nakazu zapłaty wydanego w elektronicznym postępowaniu upominawczym a uzupetnienie opłaty sądowej od pozwu, „Monitor Prawniczy” 2014, nr 11, s. 598 n.; eadem, Sprzeciw w elektronicznym postępowaniu upominawczym - uwagi na tle obowiazujacych oraz projektowanych rozwiazań legislacyjnych, „Monitor Prawniczy” 2013, nr 13, s. 678 n.; P. Sławicki, Postepowanie upominawcze po skierowaniu sprawy z elektronicznego postępowania upominawczego - wybrane zagadnienia, „Monitor Prawniczy” 2016, nr 3, s. 127 n.; J. Studzińska, Wytoczenie powództwa w elektronicznym postępowaniu upominawczym i jego umorzenie a bieg terminu przedawnienia - cz. I, „Monitor Prawniczy” 2015, nr 2, s. 65 n.; eadem, Wytoczenie powództwa w elektronicznym postępowaniu upominawczym i jego umorzenie a bieg terminu przedawnienia — cz. II, „Monitor Prawniczy” 2015, nr 3, s. 125 n.; P. Widerski, Zasqdzenie kosztów procesu po przekazaniu sprawy sądowi właściwości ogólnej z elektronicznego postępowania upominawczego przed doręczeniem pozwu stronie pozwanej, „Monitor Prawniczy” 2019, nr 4, s. 211 n.; J. Widło, A. Wróbel, Postępowanie przed sądem wtaściwości ogólnej po przekazaniu sprawy z elektronicznego postepowania upominawczego $w$ świetle art. 505[37] k.p.c. Uwagi de lege lata $i$ de lege ferenda, „Przegląd Sądowy” 2012, nr 4, s. 61 n.; N. Wójcik-Krokowska, Sprzeciw od nakazu zapłaty $w$ postepowaniu upominawczym oraz $w$ elektronicznym postępowaniu upominawczym, „Monitor Prawniczy" 2018, nr 5, s. 267 n.

7 Wyrok Trybunału Konstytucyjnego z dnia 13 marca 2012 roku, sygn. P 39/10 (Dz.U. z 2012 r. poz. 292); uchwała Sądu Najwyższego z dnia 10 października 2013 roku, sygn. III CZP 56/13, www. 
jednoznacznego ukazania, że elektroniczne postępowanie upominawcze jest jakościowo innym postępowaniem niż zwykły proces. Nieprzeprowadzenie postępowania dowodowego niewątpliwie rzutuje na charakter zapadłych w sprawie orzeczeń. Jednak żaden z tak zakreślonych hipotetycznych celów nie został zrealizowany w pełnym zakresie w ramach nowelizacji z 2019 roku. W niemałej liczbie konkretnych spraw sytuacja prawna powodów i pozwanych w elektronicznym postępowaniu upominawczym nie ulegnie istotnej zmianie, czyli nie zostaną oni pozbawieni żadnych procesowych udogodnień.

Jak już wskazano odnośnie do nowelizacji z 2019 roku, znaczna część zmian dotyczących elektronicznego postępowania upominawczego ma jedynie redakcyjny charakter. Zmiany te są jednak liczne. Może to budzić wątpliwości w świetle trafności działań legislacyjnych, ponieważ z wielu zmian nie wynikają istotne skutki. Tak jak stworzenie przepisów ogólnych (art. $480^{1} \_480^{4}$ k.p.c.) wydaje się zasadnym rozwiązaniem, to jednak niektóre przepisy otrzymały nowe brzmienie na tyle odmienne od dotychczasowej treści, że celowe byłoby stworzenie nowych numerów przepisów, a nie zastępowanie dawnych. Dotyczy to zwłaszcza art. $505^{37}$ k.p.c. - wprawdzie dotychczasowe zmiany co do przekazywania sprawy do sądu według właściwości ogólnej również były częste w ramach tego artykułu, zawsze dotyczyły jednak przekazywania sprawy. Obecne umiejscowienie regulacji mogłoby sugerować, że nowy mechanizm także jest swoistą formą przekazania sprawy (choć jej etap stanowi umorzenie tej sprawy), ale jak wynika z uzasadnienia projektu, celem było uczynienie z elektronicznego postępowania upominawczego alternatywy wobec zwykłego procesu, a nie jego części ${ }^{8}$.

\section{EFEKTYWNOŚĆ}

Wdrażanie rozwiązań informatycznych w podmiotach publicznych ma służyć zwiększeniu efektywności - w wypadku sądownictwa efektywności postępowania sądowego. Dawniej w nowych technologiach upatrywano remedium na wiele bieżących problemów — remedium o tyle atrakcyjnego, że wymagało tylko poniesienia nakładów finansowych na zakup sprzętu i oprogramowania (które wprawdzie są obciążeniem, jednak szybkim i prostym do zrealizowania, o ile są wystarczające środki budżetowe). Przez wzrost efektywności postępowania sądowego rozumiano zaś głównie jego przyśpieszenie, ewentualnie również obniżenie kosztów dla wymiaru sprawiedliwości.

sn.pl (dostęp: 14.05.2020); uchwała Sądu Najwyższego z dnia 18 października 2013 roku, sygn. III CZP 63/13, www.sn.pl (dostęp: 14.05.2020); uchwała Sądu Najwyższego z dnia 25 czerwca 2015 roku, sygn. III CZP 33/15, www.sn.pl (dostęp:14.05.2020); uchwała Sądu Najwyższego z dnia 21 listopada 2013 roku, sygn. III CZP 66/13, www.sn.pl (dostęp: 14.05.2020).

${ }^{8}$ Druk sejmowy z 8 stycznia 2019 roku, nr 3137, Sejm RP VIII kadencji, uzasadnienie projektu ustawy, s. 119, www.sejm.gov.pl (dostęp: 14.05.2020). 
Niespełna dwie dekady (licząc od fundamentalnej dawniej ustawy o podpisie elektronicznym ${ }^{9}$ ) ukazały, że informatyzacja jest jednak złożonym przedsięwzięciem prawno-organizacyjnym ${ }^{10}$. Częściowe wprowadzanie zaś rozwiązań informatycznych może prowadzić do wręcz odwrotnych skutków (choćby wynikających z dublowania się czynności w postaci elektronicznej i nieelektronicznej, a następnie konieczności ich skoordynowania, co najczęściej wymaga większego nakładu pracy, niż gdyby pozostać przy tradycyjnych rozwiązaniach). W elektronicznym postępowaniu upominawczym problem powielania się czynności w postaci tradycyjnej i elektronicznej w znacznej części udało się ograniczyć. Czynności stron i sądu dokonywane są w większości elektronicznie. W postaci wydruku występuje jedynie pozew i nakaz zapłaty (w oryginale mają postać elektroniczną) na potrzeby doręczenia ich pozwanemu. Również czynności pozwanego mogą być dokonywane w postaci nieelektronicznej, jednak są to czynności nieliczne z uwagi na konstrukcję mechanizmu procesowego elektronicznego postępowania upominawczego. Można zatem stwierdzić, że w sądzie rozpoznającym sprawy w elektronicznym postępowaniu upominawczym zdecydowanie przeważa elektroniczny obieg dokumentacji. Ponadto wydaje się, że to właśnie elektroniczny obieg dokumentów umożliwia relatywnie sprawne rozpoznawane niezwykle dużej liczby spraw w elektronicznym postępowaniu upominawczym.

Patrząc przez pryzmat celów informatyzacji podmiotów publicznych, należy również nawiązać wprost do ratio legis ustawy o informatyzacji działalności podmiotów realizujących zadania publiczne ${ }^{11}$. Ustawa ta wprost w art. 1 in fine wskazuje, że celem jej uregulowań jest „ochrona interesu publicznego, w tym zachowania przez Państwo możliwości swobody wyboru technologii w procesach informatyzacji realizacji zadań publicznych". Cele te są realizowane w szczególności poprzez dbałość o neutralność technologiczną (zdefiniowaną w art. 3 pkt 19 u.i.dz.p.r.z.p.) i interoperacyjność (zdefiniowaną w art. 3 pkt 18 u.i.dz.p.r.z.p.). Trzeba przy tym nadmienić, że pojawiające się głosy o niestosowaniu tej ustawy na gruncie postępowań sądowych nie są trafne ${ }^{12}$. Przepis art. 2 ust. 1 pkt 1 u.i.dz.p.r.z.p. jednoznacznie wskazuje na związanie sądów regulacjami tej ustawy (z wyjątkiem określonym w art. 2 ust. 4 u.i.dz.p.r.z.p., który jednak dotyczy na przykład Sądu Najwyższego, a nie sądów powszechnych).

Mając na uwadze, że czynności w elektronicznym postępowaniu upominawczym ogniskują się wokół funkcjonalności systemu teleinformatycznego obsługu-

9 Ustawa z dnia 18 września 2001 roku o podpisie elektronicznym (Dz.U. Nr 130, poz. 1450 ze zm.); dalej: u.p.e.

10 Zob. J. Gołaczyński, op. cit., s. 97 n.

11 Ustawa z dnia 17 lutego 2005 roku o informatyzacji działalności podmiotów realizujących zadania publiczne (tekst jedn. Dz.U. z 2019 r. poz. 700 ze zm.); dalej: u.i.dz.p.r.z.p.

12 Zob. uchwałę Sądu Najwyższego z dnia 23 maja 2012 roku, sygn. III CZP 9/12, www.sn.pl (dostęp: 14.05.2020); oraz P. Grzegorczyk, Dopuszczalność wniesienia środka zaskarżenia w postaci elektronicznej, „Monitor Prawniczy” 2012, nr 19, s. 1043-1047. 
jącego to postępowanie (wraz z internetowym portalem dostępowym), neutralność technologiczna i interoperacyjność są, jak się wydaje, przynajmniej w znacznym zakresie realizowane. Sprzyja również temu brak jakichkolwiek załączników w pismach procesowych, w tym dowodów (tak art. $505^{32} \S 1$ i art. $505^{35}$ k.p.c.). Innymi słowy, mechanizm procesowy elektronicznego postępowania upominawczego umożliwia funkcjonowanie we względnie jednorodnym i zamkniętym środowisku informatycznym, jeśli ujmować zagadnienie od strony użytkowania systemu teleinformatycznego, w tym dokonywania w jego ramach czynności procesowych. Odrębną kwestią jest właściwa konstrukcja tego systemu teleinformatycznego. Niestety na tym polu występują pewne niedomagania, których ustawodawca jest nawet świadomy, w związku z czym zmiany prawne muszą uwzględniać zakres funkcjonalności systemu teleinformatycznego obsługującego elektroniczne postępowanie upominawcze ${ }^{13}$.

W kontekście interoperacyjności warto dodać, że przepisy elektronicznego postępowania upominawczego od początku swojego obowiązywania zakładały integrację z innymi bazami publicznymi, co wynikało z konieczności weryfikacji danych numerycznych dotyczących stron. Pierwotnie art. $505^{32} \S 2$ k.p.c. przewidywał jedynie podawanie numeru Powszechnego Elektronicznego Systemu Ewidencji Ludności (PESEL), numeru identyfikacji podatkowej (NIP), numeru w Krajowym Rejestrze Sądowym (KRS) lub numeru w innym właściwym rejestrze i ewidencji powoda (numer PESEL był rzeczywiście potrzebny już na etapie zakładania konta w systemie teleinformatycznym obsługującym elektroniczne postępowanie upominawcze). Od nowelizacji z 2013 roku $^{14}$ zakres podawanych danych uległ rozszerzeniu o informacje o pozwanym (nowe brzemienia art. $126 \S 2$ oraz art. $505^{32} \S 2$ k.p.c.). Ponadto na potrzeby każdego postępowania cywilnego wprowadzono art. $208^{1}$ k.p.c., stanowiący, że sąd z urzędu ustala numer PESEL pozwanego będącego osobą fizyczną, jeżeli jest on obowiązany do jego posiadania lub posiada go, nie mając takiego obowiązku, lub numer w KRS, a w wypadku jego braku - numer w innym właściwym rejestrze bądź ewidencji lub NIP pozwanego niebędącego osobą fizyczną, który nie ma obowiązku wpisu we właściwym rejestrze lub ewidencji, jeżeli jest on obowiązany do jego posiadania. Mocą nowelizacji z 2019 roku numer PESEL jest też wykorzystywany na potrzeby doręczeń w elektronicznym postępowaniu upominawczym, gdyż zgodnie z art. $505^{34}$ $\S 1$ in fine k.p.c. w razie niemożności skutecznego doręczenia nakaz zapłaty uznaje

13 W kontekście nowelizacji z 2019 roku w uzasadnieniu projektu wskazano wprost, że „ograniczenia techniczne systemu teleinformatycznego obsługującego e.p.u. powodują konieczność utrzymania w tym postępowaniu, jako wyjątków, niektórych regulacji obowiązujących dotychczas w ogólnych przepisach o procesie lub w zwykłym postępowaniu upominawczym" - druk sejmowy z 8 stycznia 2019 roku..., s. 119.

14 Ustawa z dnia 10 maja 2013 roku o zmianie ustawy — Kodeks postępowania cywilnego (Dz.U. z 2013 r. poz. 654). 
się za doręczony, o ile adres, pod którym pozostawiono zawiadomienia, jest zgodny $z$ adresem ujawnionym $w$ rejestrze PESEL.

Na marginesie tylko należy zauważyć, że elektroniczne postępowanie upominawcze wciąż stanowi jedyne postępowanie zawarte w dziale VIII „Postępowania elektroniczne" w części pierwszej w księdze pierwszej w tytule VII k.p.c. Jakby się wydawało, elektroniczne postępowanie upominawcze zostało wprowadzone jako pierwsze z kilku planowanych odrębnych postępowań elektronicznych. Przy czym jeszcze w chwili ustanawiania elektronicznego postępowania upominawczego nie było oczywiste, jakie miałyby to być kolejne postępowania. Można się jedynie domyślać i wskazać na elektroniczne postępowanie nakazowe lub elektroniczne europejskie postępowanie nakazowe.

Co ciekawe, w chwili powstania elektroniczne postępowanie upominawcze było projektowane jako alternatywna względem postępowania w sprawach gospodarczych, dlatego ustanowiono art. 479a zd. 2 k.p.c., który wyłączał stosowanie regulacji o postępowaniu w sprawach gospodarczych w wypadku spraw gospodarczych rozpoznawanych w elektronicznym postępowaniu upominawczym. Po zlikwidowaniu postępowania w sprawach gospodarczych i jego ponownym wprowadzeniu mocą nowelizacji z 2019 roku ustanowiono nowy przepis — art. $458^{1} \S 2$ k.p.c. - o analogicznej treści jak dawny art. 479a k.p.c. Elektroniczne postępowanie upominawcze okazało się zatem trwalsze w ostatniej dekadzie niż zmiany dotyczące postępowania w sprawach gospodarczych.

\section{NIESPÓJNA EWOLUCJA INSTYTUCJI PROCESOWYCH}

Przepisy dotyczące elektronicznego postępowania upominawczego były wcale nierzadko nowelizowane. Zmiany ukierunkowane były głównie na obostrzenie w korzystaniu, przede wszystkim przez powoda, z różnych przywilejów i narzędzi informatycznych, a tym samym poprawę sytuacji prawnej pozwanego ${ }^{15}$. Kolejne zmiany nie zawsze jednak były spójne. Przykładem jest choćby kwestia wniosku o warunkowe umorzenie postępowania. Do wprowadzenia tej instytucji do elektronicznego postępowania upominawczego ustawodawca podchodził niezwykle ostrożnie, mimo że już wcześniej analogiczne rozwiązanie funkcjonowało w europejskim postępowaniu nakazowym (art. $505^{19} \S 4$ k.p.c. i art. 17 ust. 1 rozporzą-

15 Por. m.in. A. Kościółek, Wzmocnienie pozycji dtużnika w postępowaniu egzekucyjnym $w$ świetle ustawy z dnia 10 maja 2013 r. o zmianie ustawy - Kodeks postepowania cywilnego, „Przegląd Sądowy” 2013, nr 7-8, s. 90 n.; J. Jankowski, Nowelizacja Kodeksu postępowania cywilnego dokonana moca ustawy z 10.5.2013 r., „Monitor Prawniczy” 2013, nr 15, s. 792 n.; P. Fik, Art. 505[29a] k.p.c. na tle nowelizacji z 10 maja 2013 r. - uwag kilka, „Przegląd Sądowy” 2014, nr 5, s. 123 n.; R. Flejszar, Postepowania przyspieszone po zmianach wprowadzonych nowelizacja KPC z 4.7.2019 r., „Monitor Prawniczy” 2019, nr 21, s. 1176 n. 
dzenia nr 1896/2006 ${ }^{16}$ ). Ustanowiono ją dopiero nowelizacją z lipca 2015 roku, która w tym zakresie miała wydłużone vacatio legis (nowelizacja weszła w życie z dniem 8 września 2016 roku, a analizowany wniosek o warunkowe umorzenie postępowania dopiero od 1 marca 2017 roku). Ponadto takie zastosowanie wniosku zostało ograniczone do braku podstaw do wydania nakazu zapłaty (art. $505^{33}$ $\S 3$ k.p.c.) i przypadku uchylenia nakazu zapłaty (art. $505^{34} \S 3$ k.p.c.). Nie było więc możliwości jego zastosowania na wypadek wniesienia sprzeciwu, czyli kluczowej sytuacji procesowej. Korzyści z takiego wniosku byłyby dla powoda wtedy największe. Dla tego przypadku skorzystanie z przedmiotowego wniosku nie było możliwe z uwagi na obawy co do nadużyć, zwłaszcza pochopnego składania pozwów. Tymczasem w nowelizacji z 2019 roku kierowano się całkiem innym założeniem i umorzenie postępowania stało się zasadą w każdym przypadku, czyli nawet nie będzie konieczny wniosek powoda.

Wreszcie nierzadko kolejne zmiany informatyczne w postępowaniu cywilnym polegały na nadawaniu niestosowalnym (pustym) regulacjom nowego brzmienia. Nowy przepis był najczęściej równie niestosowalny. Najbardziej znamiennym przykładem chybionej legislacji związanej z informatyzacją jest regulacja art. 125 k.p.c. Przynajmniej trzykrotnie przepisy tego artykuły miały być przełomowe dla informatyzacji, co nastąpiło jedynie w wypadku wdrożenia elektronicznego postępowania upominawczego. Przy czym dla przedmiotowego postępowania, zwłaszcza w pierwszych latach jego funkcjonowania, regulacja ta nie miała istotnego znaczenia, a jedynie stanowiła wyraz dostosowania dotychczasowych regulacji do nowych przepisów statuujących elektroniczne postępowanie upominawcze.

Pierwotnie, mocą nowelizacji z 2000 roku $^{17}$, w art. $125 \S 2$ k.p.c. statuowano wnoszenie pism procesowych na elektronicznych nośnikach informatycznych (przepis ten uzupełniał $\S 4$ tego artykułu, stanowiący delegację dla Minister Sprawiedliwości do określenia w drodze rozporządzenia szczegółowych kwestii z tym związanych — rozporządzenie takie nie zostało jednak nigdy wydane). Nowelizacja z 2008 roku $^{18}$ w miejsce elektronicznych nośników informatycznych w przywołanych regulacjach wprowadziła informatyczne nośniki danych lub wnoszenie pism za pośrednictwem środków komunikacji elektronicznej. Zmiana ta nie przełożyła się na zmiany w procesie cywilnym. Dopiero nowelizacja z 2009 roku $^{19}$,

16 Rozporządzenie UE nr 1896/2006 Parlamentu Europejskiego i Rady z dnia 12 grudnia 2006 roku ustanawiające postępowanie w sprawie europejskiego nakazu zapłaty (Dz.Urz. UE L 399 z 30.12.2006 r., s. 1-32 ze zm.).

17 Ustawa z dnia 24 maja 2000 roku o zmianie ustawy - Kodeks postępowania cywilnego, ustawy o zastawie rejestrowym i rejestrze zastawów, ustawy o kosztach sądowych w sprawach cywilnych oraz ustawy o komornikach sądowych i egzekucji (Dz.U. Nr 48, poz. 554), która w tym zakresie weszła w życie 1 października 2000 roku.

18 Ustawa o zmianie ustaw w celu ujednolicenia terminologii informatycznej z dnia 4 września 2008 roku (Dz.U. Nr 171, poz. 1056), która weszła w życie 8 października 2008 roku.

19 Ustawa o zmianie ustawy - Kodeks postępowania cywilnego oraz niektórych innych ustaw z dnia 9 stycznia 2009 roku (Dz.U. Nr 26, poz. 156), która weszła w życie 1 stycznia 2010 roku. 
która wprowadziła elektroniczne postępowanie upominawcze, miała doniosłe znaczenie praktyczne. Od wejścia w życie tej noweli mowa była bowiem o wnoszeniu pism procesowych za pomocą systemu teleinformatycznego (drogą elektroniczną) lub na informatycznych nośnikach danych.

Daleko idące zmiany pod względem legislacyjnym, ale nieistotne praktycznie, zostały dokonane nowelizacją z $2011 \mathrm{roku}^{20}$. Materię informatyczną usunięto wtedy całkowicie $\mathrm{z}$ art. 125 § 2 k.p.c. (w którym pozostawiono jedynie regulację dotyczącą pism procesowych na urzędowych formularzach) i ustanowiono nowy art. $125 \S 2^{1}$ k.p.c. W nowej regulacji art. $125 \S 2^{1}$ zd. 1 k.p.c. wskazano na możliwość (jeżeli przepis szczególny tak stanowi) wnoszenia pism procesowych za pomocą systemu teleinformatycznego obsługującego postępowanie sądowe (drogą elektroniczną). Ponadto w art. $125 \S 2^{1}$ zd. 2 k.p.c. wskazano, że jeżeli przepis szczególny przewiduje, że pisma wnosi się wyłącznie drogą elektroniczną, pisma niewniesione tą drogą nie wywołują skutków prawnych, jakie ustawa wiąże $\mathrm{z}$ wniesieniem pisma do sądu. W art. $125 \S 3^{1}$ k.p.c. (§ 4 tego artykułu został uchylony) zaś zawarto delegacje dla Ministra Sprawiedliwości do określenia w drodze rozporządzenia, w porozumieniu z ministrem właściwym do spraw informatyzacji, sposobu wnoszenia pism procesowych drogą elektroniczną.

Dalsze zmiany w art. $125 \S 2^{1}$ zd. 1 k.p.c. wprowadziła nowelizacja ze stycznia $2015 \mathrm{roku}^{21}$. Usunięto wtedy pojęcie drogi elektronicznej, a przepis otrzymał brzmienie: ,jeżeli przepis szczególny tak stanowi, pisma procesowe wnosi się za pośrednictwem systemu teleinformatycznego obsługującego postępowanie sądowe (system teleinformatyczny)". Nowelizacji tej towarzyszyło zrealizowanie delegacji do wydania rozporządzenia $\mathrm{z}$ art. $125 \S 3^{1}$ k.p.c., który to akt normatywny wciąż obowiązuje $^{22}$. Kolejne zmiany, jak się okazało po latach nieistotne z praktycznego punktu widzenia, przyniosła nowelizacja z lipca 2015 roku $^{23}$. Przepis art. $125 \S 2^{1}$ zd. 1 k.p.c. stanowił odtąd, że, ,jeżeli przepis szczególny tak stanowi albo dokonano wyboru wnoszenia pism procesowych za pośrednictwem systemu teleinformatycznego, pisma procesowe w tej sprawie wnosi się wyłącznie za pośrednictwem systemu teleinformatycznego". W ramach tej nowelizacji ustanowiono również, rozwijające kwestie informatyczne, uregulowania art. $125 \S 2^{2}-2^{4}$ k.p.c.

${ }^{20}$ Ustawa z dnia 16 września 2011 roku o zmianie ustawy — Kodeks postępowania cywilnego oraz niektórych innych ustaw (Dz.U. Nr 233, poz. 1381), która weszła w życie 3 maja 2012 roku.

${ }^{21}$ Ustawa z dnia 15 stycznia 2015 roku o zmianie ustawy - Kodeks postępowania cywilnego oraz niektórych innych ustaw (Dz.U. z 2015 r. poz. 218 ze zm.), która weszła w życie 1 lipca 2016 roku.

22 Rozporządzenie Ministra Sprawiedliwości z dnia 20 października 2015 roku w sprawie sposobu wnoszenia pism procesowych za pośrednictwem systemu teleinformatycznego obsługującego postępowanie sądowe (Dz.U. z 2015 r. poz. 1783 ze zm.).

23 Ustawa z dnia 10 lipca 2015 roku o zmianie ustawy — Kodeks cywilny, ustawy — Kodeks postępowania cywilnego oraz niektórych innych ustaw (Dz.U. z 2015 r. poz. 1311), która weszła w życie 8 września 2016 roku. 
Nowelizacja z 2019 roku istotnie podważyła skuteczność drugiej ze wspomnianych nowelizacji z 2015 roku. Ustanowiono wtedy art. $125 \S 2^{\text {la }}$ k.p.c., w myśl którego „dokonanie wyboru wnoszenia pism procesowych za pośrednictwem systemu teleinformatycznego oraz dalsze wnoszenie tych pism za pośrednictwem tego systemu jest dopuszczalne, jeżeli z przyczyn technicznych, leżących po stronie sądu, jest to możliwe". Możliwość wyboru elektronicznego wnoszenia pism uzależniono zatem od uwarunkowań technicznych sądu — wskutek zaś braku takich technicznych uwarunkowań prawo do wyboru w tym zakresie ma jedynie charakter iluzoryczny.

Regulacja elektronicznego postępowania była również zmieniana przez swoistą redukcję regulacji. Nie dochodziło do eliminacji samych rozwiązań, lecz do pozbawienia ich podstawy prawnej. Przykładowo założeniem ustawodawcy przy tworzeniu elektronicznego postępowania upominawczego było stworzenie specjalnego mechanizmu wymiany informacji między sądem a powodami masowymi. Znamienne jest, że miało się to przyczynić do ułatwienia pracy zarówno sądowi, jak i stronie, ponieważ umożliwiało lepsze strukturyzowanie informacji, w tym uwidocznienie ich powtarzalności, a przez to łatwiejsze zapoznawanie się z ich treścią ${ }^{24}$. Wyrazem legislacyjnym tego założenia była instytucja użytkowników masowych (nazywanych potocznie powodami masowymi), uregulowana wprawdzie nie w k.p.c., lecz w akcie wykonawczym. Zgodnie z § 2 pkt 4 nieobowiązującego już rozporządzenia Ministra Sprawiedliwości w sprawie trybu zakładania konta oraz sposobu posługiwania się podpisem elektronicznym w elektronicznym postępowaniu upominawczym ${ }^{25}$ przez użytkownika masowego rozumiało się użytkownika komunikującego się z sądem właściwym do prowadzenia elektronicznego postępowania upominawczego za pomocą przeznaczonego do tego celu własnego oprogramowania. W nowym rozporządzeniu Minister Sprawiedliwości w sprawie trybu zakładania i udostępniania konta w systemie teleinformatycznym obsługującym postępowanie sądowe ${ }^{26}$ instytucja użytkownika masowego nie została już przewidziana. Pomimo braku regulacji z użytkownikami masowymi wciąż funkcjonują oni w elektronicznym postępowaniu upominawczym na poziomie technicznym.

Kolejnym przykładem redukcji legislacji jest kwestia podpisu elektronicznego. Pierwotnie (mocą nowelizacji z 2009 roku) rodzaj podpisu elektronicznego regulował art. $126 \S 5$ k.p.c., w myśl którego pismo procesowe wniesione drogą elektroniczną powinno być opatrzone podpisem elektronicznym w rozumieniu art. 3 pkt 1

24 Por. D. Segit, P. Telusiewicz, Możliwości usprawnienia wspótpracy e-sądu z powodami masowymi - uwagi na tle doświadczeń praktycznych, „Monitor Prawniczy” 2013, nr 6, s. 329 n.

25 Rozporządzenie Ministra Sprawiedliwości z dnia 28 grudnia 2009 roku w sprawie trybu zakładania konta oraz sposobu posługiwania się podpisem elektronicznym w elektronicznym postępowaniu upominawczym (Dz.U. Nr 226, poz. 1830).

${ }^{26}$ Rozporządzenie Ministra Sprawiedliwości z dnia 26 kwietnia 2016 roku w sprawie trybu zakładania i udostępniania konta w systemie teleinformatycznym obsługującym postępowanie sądowe (Dz.U. poz. 637 ze zm.). 
u.p.e. ${ }^{27}$ Był to zatem tak zwany zwykły podpis elektroniczny. Nowelizacja ze stycznia 2015 roku radykalnie zmieniła jednak stan rzeczy w zakresie podpisu elektronicznego, wskazując na konieczność posługiwania się bezpiecznym podpisem elektronicznym weryfikowanym przy pomocy ważnego kwalifikowanego certyfikatu lub podpisem potwierdzonym profilem zaufanym ePUAP (obecnie uległy zmianie nazwy tych instytucji i pojawiły się nowe, w związku z czym art. $126 \S 5$ k.p.c. mówi o kwalifikowanym podpisie elektronicznym, podpisie zaufanym i podpisie osobistym). Takie rozwiązanie znacznie utrudniłoby korzystanie z elektronicznego postępowania upominawczego. Wydaje się przy tym, że zmiana ta nie była w tym zakresie zamierzona i przypadkowa w kontekście elektronicznego postępowania upominawczego. Dlatego jeszcze przed wejściem w życie nowelizacji ze stycznia 2015 roku dokonano kolejnej zmiany (nowelizacją z lipca tego samego roku), ustanawiając art. $505^{31}$ ust. $2^{1}$ k.p.c., stanowiący, że pisma wniesione w elektronicznym postępowaniu upominawczym za pośrednictwem systemu teleinformatycznego nie wymagają opatrzenia ich podpisem, o którym mowa w art. $126 \S 5$ k.p.c.

W efekcie stosowanie normy art. $126 \S 5$ k.p.c., pierwotnie stworzonej na potrzeby elektronicznego postępowania upominawczego, zostało wyłączone w tym postępowaniu. Problematyczna jednak jest nie tyle sama ewolucja legislacji, ile poprzestanie ustawodawcy na stworzeniu normy negatywnej w art. $505^{31}$ ust. $2^{1}$ k.p.c. Przepis ten mówi jedynie o tym, jakich podpisów nie trzeba stosować w elektronicznym postępowaniu upominawczym, brakuje jednak normy wskazującej, jakim przepisem elektronicznym należy posłużyć się jako zamiennikiem podpisów wskazanych $\mathrm{w}$ art. $126 \S 5$ k.p.c. Nie można przy tym posłużyć się odesłaniem do normy ogólnej, gdyż stosowanie normy ogólnej, czyli art. $126 \S 5$ k.p.c., zostało wprost wyłączone. Również gdyby odwoływać się do uregulowań pozakodeksowych, odnalazłoby się jako zasadę posługiwanie się podpisami wskazanymi w art. $126 \S 5$ k.p.c. Posługiwanie się obecnie w elektronicznym postępowaniu upominawczym ,zwykłym” podpisem elektronicznym opiera się zatem na dawnym, już nieobowiązującym, art. $126 \S 5$ k.p.c.

\section{PODSUMOWANIE}

Niewątpliwie, niezależnie od kilku mankamentów, elektroniczne postępowanie upominawcze było przełomowe dla informatyzacji podmiotów publicznych. Wyznaczyło bowiem kierunki informatyzacji postępowania cywilnego, przynajmniej na poziomie konkretnych instytucji procesowych. Co więcej, wciąż jest

27 Obecnie ustawa ta nie obowiązuje, a definicja „zwykłego” podpisu elektronicznego znajduje się w art. 3 pkt 10 rozporządzenia Parlamentu Europejskiego i Rady (UE) nr 910/2014 z dnia 23 lipca 2014 roku w sprawie identyfikacji elektronicznej i usług zaufania w odniesieniu do transakcji elektronicznych na rynku wewnętrznym oraz uchylające dyrektywę 1999/93/WE (Dz.Urz. UE L 2014 Nr 257, s. 73). 
rozwiązaniem innowacyjnym $\mathrm{i}$ - jak się okazuje — niezastępowalnym w strukturze wymiaru sprawiedliwości. Warto w tym miejscu wyjaśnić, że gdyby nowelizacja z 2016 roku została zrealizowana w pełni, wskutek funkcjonowania obok elektronicznego postępowania upominawczego zinformatyzowanego zwykłego postępowania upominawczego mogłoby dojść do stopniowej marginalizacji tego pierwszego postępowania, a w efekcie nawet do całkowitego przejęcia jego roli przez drugie postępowanie. Niemożność wdrożenia w procesie cywilnym bardziej uniwersalnych rozwiązań informatycznych skłoniła jednak ustawodawcę do odejścia od pierwotnych założeń. Pomimo że elektroniczne postępowanie upominawcze funkcjonuje wiele lat, to nawet $\mathrm{w}$ wypadku postępu informatycznego w konkurencyjnych względem niego postępowaniach cywilnych możliwy jest jego rozwój przez zautomatyzowanie orzekania, a tym samym odróżnienie go przede wszystkim od zinformatyzowanego zwykłego postępowania cywilnego.

\section{ELECTRONIC WRIT OF PAYMENT IN THE CONTEXT OF THE PURPOSES OF COMPUTERISATION OF PUBLIC ENTITIES}

Summary

Electronic writ of payment was the first successful IT implementation in civil proceedings. For a period of ten years the role of this procedure in the civil procedure system was significant. It still has potential for further development. However, legal regulations have changed many times. The new legal regulations have not always been accurate and consistent.

Keywords: e-court, computerisation, civil proceedings, electronic writ of payment, law

\section{BIBLIOGRAFIA}

Antoniuk J.R., Postępowanie sądu właściwego po przekazaniu mu sprawy wniesionej w elektronicznym postępowaniu upominawczym (uwagi na tle art. 505 [37] KPC), „Monitor Prawniczy” 2012, nr 20.

Antoniuk J.R., Pozew i sprzeciw od nakazu zapłaty wniesione $w$ elektronicznym postepowaniu upominawczym po przekazaniu sprawy do sąu właściwego (uwagi na tle znowelizowanego art. 505[37] k.p.c.), „Polski Proces Cywilny” 2015, nr 4.

Fik P., Art. 505[29a] k.p.c. na tle nowelizacji z 10 maja 2013 r. - uwag kilka, „Przegląd Sądowy” 2014, nr 5.

Flejszar R., Posteppowania przyspieszone po zmianach wprowadzonych nowelizacją KPC z 4.7.2019 r., „Monitor Prawniczy” 2019, nr 21.

Gołaczyński J., e-Sąd przyszłości, „Monitor Prawniczy” 2019, nr 2.

Goździaszek Ł., Elektroniczne postępowanie upominawcze po nowelizacji, [w:] Kodeks postępowania cywilnego z perspektywy pięćdziesięciolecia jego obowiązywania. Doświadczenia i perspektywy, red. E. Marszałkowska-Krześ, I. Gil, Ł. Błaszczak, Sopot 2016. 
Goździaszek Ł., Funkcjonowanie elektronicznego postępowania upominawczego, „Biuletyn Polskiego Towarzystwa Ekonomicznego" 2017, nr 2.

Goździaszek Ł., Konsekwencje dla strony przekazania sprawy z e-sadu, [w:] Elektroniczne postepowanie upominawcze - doświadczenia i perspektywy, red. K. Flaga-Gieruszyńska, A. Jakubecki, J. Misztal-Konecka, Lublin 2017.

Goździaszek Ł., Perspektywy petnego zautomatyzowania elektronicznego postępowania upominawczego, [w:] E-obywatel. E-sprawiedliwość. E-ustugi, red. K. Flaga-Gieruszyńska, J. Gołaczyński, D. Szostek, Warszawa 2017.

Goździaszek Ł., Perspektywy wykorzystania sztucznej inteligencji w postępowaniu sądowym, „Przegląd Sądowy" 2015.

Goździaszek Ł., Sprawność postępowania zwyktego, postępowania gospodarczego i elektronicznego postepowania upominawczego, [w:] Ochrona praw wierzycieli w Polsce - wymiar ekonomiczny, koszty transakcyjne, prawne formy zabezpieczeń, informatyzacja sadownictwa, red. J. Gołaczyński, E. Mączyńska, Warszawa 2017.

Goździaszek Ł., Sytuacja spółek jako wierzycieli dochodzacych roszczeń w elektronicznym postępowaniu upominawczym, postępowaniu nakazowym i zwyktym postępowaniu cywilnym, „Biuletyn Polskiego Towarzystwa Ekonomicznego" 2016, nr 4.

Grzegorczyk P., Dopuszczalność wniesienia środka zaskarżenia w postaci elektronicznej, „Monitor Prawniczy" 2012, nr 19.

Jankowski J., Nowelizacja Kodeksu postepowania cywilnego dokonana moca ustawy z 10.5.2013 r., „Monitor Prawniczy” 2013, nr 15.

Jasik-Kuchta K., Proponowane zmiany w polskim elektronicznym postepowaniu upominawczym w świetle rozwiazań Online Civil Money Claims, „Monitor Prawa Handlowego” 2018, nr 4.

Kaczmarek-Templin B., Zmiany w elektronicznym postepowaniu upominawczym i zmiany w elektronicznych doręczeniach $w$ świetle nowelizacji Kodeksu postępowania cywilnego z 27.11.2017 r., „Prawo Mediów Elektronicznych” 2018, nr 2.

Kościółek A., Sprzeciw od nakazu zapłaty wydanego w elektronicznym postępowaniu upominawczym a uzupetnienie opłaty sądowej od pozwu, „Monitor Prawniczy” 2014, nr 11.

Kościółek A., Sprzeciw w elektronicznym postępowaniu upominawczym - uwagi na tle obowiazujacych oraz projektowanych rozwiazań legislacyjnych, „Monitor Prawniczy” 2013, nr 13.

Kościółek A., Wzmocnienie pozycji dtużnika w postępowaniu egzekucyjnym w świetle ustawy z dnia 10 maja 2013 r. o zmianie ustawy - Kodeks postępowania cywilnego, „Przegląd Sądowy” 2013, nr 7-8.

Segit D., Telusiewicz P., Możliwości usprawnienia wspótpracy e-sądu z powodami masowymi uwagi na tle doświadczeń praktycznych, „Monitor Prawniczy” 2013, nr 6.

Sławicki P., Postępowanie upominawcze po skierowaniu sprawy z elektronicznego postepowania upominawczego - wybrane zagadnienia, „Monitor Prawniczy” 2016, nr 3.

Studzińska J., Wytoczenie powództwa w elektronicznym postępowaniu upominawczym i jego umorzenie a bieg terminu przedawnienia - cz. I, „Monitor Prawniczy” 2015, nr 2.

Studzińska J., Wytoczenie powództwa w elektronicznym postępowaniu upominawczym i jego umorzenie a bieg terminu przedawnienia - cz. II, „Monitor Prawniczy” 2015, nr 3.

Widerski P., Zasadzenie kosztów procesu po przekazaniu sprawy sądowi właściwości ogólnej z elektronicznego postepowania upominawczego przed doręczeniem pozwu stronie pozwanej, „Monitor Prawniczy" 2019, nr 4.

Widło J., Wróbel A., Postępowanie przed sądem właściwości ogólnej po przekazaniu sprawy z elektronicznego postępowania upominawczego w świetle art. 505[37] k.p.c. Uwagi de lege lata $i$ de lege ferenda, „Przegląd Sądowy” 2012.

Wójcik-Krokowska N., Sprzeciw od nakazu zapłaty w postępowaniu upominawczym oraz w elektronicznym postępowaniu upominawczym, „Monitor Prawniczy” 2018, nr 5. 